\title{
Impact of potassium rates and their application time on dry matter partitioning, biomass and harvest index of maize (Zea mays) with and without cattle dung application
}

\author{
Asif lqbal', Amanullah ${ }^{1 *}$, Mazhar lqbal ${ }^{2}$ \\ ${ }^{1}$ Department of Agronomy, Faculty of Crop Production Sciences, The University of Agriculture, Peshawar-25130; ${ }^{2}$ Department of Botany, \\ SBB University, Sheringal, Upper Dir-Pakistan
}

\section{A B S TR A C T}

\begin{abstract}
Two field experiments were conducted to study the response of maize (Zea mays L., cv. Azam) to potassium (K) levels (30, 60, $90 \mathrm{~kg}$ ha-1) and $\mathrm{K}$ application time $\left(\mathrm{T}_{1}=\right.$ full at sowing, $\mathrm{T}_{2}=$ full at $\mathrm{V} 9$ stage (many ear shoots were easily visible upon dissection), and $\mathrm{T}_{3}=50 \%$

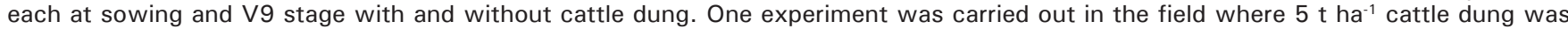
applied ( 15 days before sowing), while the field under second experiment received no cattle dung $\left(0 \mathrm{t} \mathrm{ha}^{-1}\right)$. The research was carried out at the Agronomy Research Farm of The University of Agriculture Peshawar during summer 2014. The experiments under both treatments were laid out in randomized complete block design using three replications. The results revealed that the $\mathrm{K}$ treated plots (rest) under both treatments had produced more number of leaves plant ${ }^{-1}$ and mean leaf area, partitioned more dry matter into various plant parts (leaf, stem and ear), and produced more biomass yield and harvest index than control (K not applied). Cattle dung was found more beneficial in terms of more number of leaves plant ${ }^{-1}$, higher mean leaf area, partitioning of more dry matter into leaf, stem and ear, and producing higher biomass yield and harvest index as compared to the treatment that received no cattle dung. Increasing the rate of $K$ increased number of leaves plant ${ }^{-1}$ and mean leaf area, partitioned more dry matter into various plant parts (leaf, stem and ear), produced more biomass yield and harvest index and vice versa $\left(90 \mathrm{~kg} \mathrm{~K} \mathrm{ha}^{-1}>60 \mathrm{~kg} \mathrm{~K} \mathrm{ha}^{-1}>30 \mathrm{~kg} \mathrm{~K} \mathrm{ha}^{-1}\right)$. Increase in number of leaves plant ${ }^{-1}$, mean leaf area, dry matter partitioning into various plant parts (leaf, stem and ear), biomass yield and harvest index was observed when $\mathrm{K}$ was applied in two equal splits $(50 \%$ each at sowing and V9 stage $>100 \%$ at sowing $>100 \%$ at V9 stage). It was concluded from this study that application of $\mathrm{K}$ at the highest rate of $90 \mathrm{~kg} \mathrm{ha}^{-1}$ in two equal splits (50\% at sowing $+50 \%$ at V9 stage) along with cattle dung (5 tha-1) could improve number and area of leaves, dry matter partitioning, biomass yield and harvest index under limited irrigation condition.
\end{abstract}

Keywords: Cattle manure; Potassium; Maize; Leaf area; Dry matter portioning; Growth stages; Biomass yield; Harvest index

\section{INTRODUCTION}

Maize (Zea mays L.) is the third most important cereal crop in Pakistan after wheat and rice. In Northwest Pakistan (Khyber Pakhtunkhwa) it ranked $2^{\text {nd }}$ after wheat in its importance. During 2012, maize was cultivated on an area of 1087.3 thousand hectares with the total production of 4338.3 thousand tons and national average yield of $3990 \mathrm{~kg} \mathrm{ha}^{-1}$, while in Northwest Pakistan (Khyber Pakhtunkhwa) it is grown on about 475.3 thousand hectares with a total production of 887.8 thousand tones and very low average yield of $1868 \mathrm{~kg} \mathrm{ha}^{-1}$ (MINFAL, 2012). In Northwest Pakistan, the main reason for low yield of maize is attributed to the imbalanced use of chemical fertilizers (Amanullah et al., 2010a, 2012, 2014). The farmers in this region apply potassium $(\mathrm{K})$ only to tobacco crop because of industry regulations, and the two major crops (wheat and maize) do not received any K. Potassium deficiency has been reported in many soils of Pakistan due to intensive cropping system (Malik et al., 1989; Ahmad and Rashid, 2003; Akhtar et al., 2003) because significant quantity of K is removed by crops (Singh and Jones, 1975; Mengel et al., 2001; White, 2003). Under K deficient soils, photosynthesis is significantly reduced (Hermans et al., 2006) which is responsible for low yield in maize (Asif et al., 2007; Amanullah et al., 2007), brassica (Amanullah et al., 2011)

\footnotetext{
${ }^{*}$ Corresponding author:

Amanullah, Department of Agronomy, Faculty of Crop Production Sciences, The University of Agriculture, Peshawar-25130.

E-mail: amanullah@aup.edu.pk
} 
and sunflower (Amanullah and Khan, 2010). Potassium is known to play a significant role in the activation of more than 60 enzymes which catalyze various metabolic processes (Evans and Wildes, 1971), and helps in uptake and translocation of nitrates from root to aerial parts of plants (Das et al., 1976).

Proper application and management of organic manures and chemical fertilizers contribute about 50 to $60 \%$ increases in field crops productivity (DIPA, 2006). Several organic materials such as cattle dung, poultry dropping, pig dung and refuse compost have been recommended to increase crop yield in different parts of the world (Reijnties et al., 1992; Sobulo and Babalola, 1992; Olayinka, 1996; Olayinka et al., 1998; Ismail et al., 1999; Adepetu et al., 2005; Ayoola and Makinde, 2008; Hidayatullah et al., 2013). Nutrients contained in organic manures are released more slowly and are stored for a longer time in the soil, thereby ensuring a long residual effect (Sharma et al., 1991; Hidayatullah et al., 2013). Cattle dung is an important resource for crop production and restores essential nutrients depleted due to intensive cropping practices (Sharpley and Smith, 1995; Bahman and James, 1999; Materechera, 2010). There is lack of research to investigate impact of combine application of potassium and cattle dung on maize growth and yield. This research project was therefore designed with an objective to find out suitable $\mathrm{K}$ level and its application time with and without cattle manures to increase maize productivity under potassium deficient soils.

\section{MATERIALS AND METHODS}

Field experiments were conducted to investigate the effects of potassium levels $\left(30,60,90 \mathrm{~kg} \mathrm{ha}^{-1}\right)$ and its application time (full (100\%) at sowing, full (100\%) at V9 stage: Many ear shoots were easily visible upon dissection (Amanullah et al., 2010b), and 50\% each at sowing and V9 stage) on growth and yield of maize (cv. Azam) with $\left(5 \mathrm{t} \mathrm{ha}^{-1}\right)$ and without $\left(0 \mathrm{t} \mathrm{ha}^{-1}\right)$ cattle dung (CD). The well decomposed and dry $\mathrm{CD}\left(5 \mathrm{tha}^{-1}\right)$ was applied to the field 15 days before sowing of maize crop. The research was carried out at the Agronomy Research Farm of The University of Agriculture Peshawar, during summer 2014. The experimental farm is located at $34.01^{\circ} \mathrm{N}$ latitude, $71.35^{\circ} \mathrm{E}$ longitude, at an altitude of $350 \mathrm{~m}$ above sea level in Peshawar valley. Peshawar $\left(34.0167^{\circ} \mathrm{N}\right.$ and $\left.71.5833^{\circ} \mathrm{E}\right)$ is located about $1600 \mathrm{~km}$ North of the Indian Ocean and has continental type of climate. The research farm is irrigated by Warsak canal from river Kabul. Soil is clay loam, low in organic matter $(0.87 \%)$, phosphorus $\left(6.57 \mathrm{mg} \mathrm{kg}^{-1}\right)$, potassium (121 mg kg-1) and alkaline ( $\mathrm{pH} 8.2)$ and is calcareous in nature (Amanullah et al., 2009). The experiment was performed in randomized complete block design having three replications. A plot size of $3 \mathrm{~m} \times 3.5 \mathrm{~m}$ was used. Each plot consisted of five rows, $3 \mathrm{~m}$ long and $70 \mathrm{~cm}$ apart. A uniform dose of $120 \mathrm{~kg} \mathrm{~N} \mathrm{ha}^{-1}$ as urea in two equal splits i.e. half at sowing, and half at V9 stage was applied. Phosphorus was applied at the rate of $60 \mathrm{~kg} \mathrm{P}_{2} \mathrm{O}_{5} \mathrm{ha}^{-1}$ as single super phosphate at seedbed preparation. All other agronomic practices were kept uniform and normal for all the treatments. Data were recorded on growth parameters (number of leaves plant ${ }^{-1}$ and mean leaf area), dry matter partitioning at silking and physiological maturity (stem, leaf and ear), biomass yield and harvest index. Data on number of leaves plant ${ }^{-1}$ was recorded by counting the total number of leaves on five randomly selected plants and average was calculated. Leaf area index was calculated as leaf area per plant divided by ground area per plant. For data on dry matter partitioning at silking and physiological maturity, five plants at each stage were harvested. The leaves, stem and ears were separated. The materials were sun dried up to constant weight. The materials were weighed by electronic balance and then dry weight of leaf, stem, and ears per plant was determined. Data on biomass yield was recorded by harvesting three central rows in each plot, the material was sun dried for several days and weighed, and then converted into biomass yield $\left(\mathrm{kg} \mathrm{ha}^{-1}\right)$. The dry material harvest for biomass yield was threshed; the grains were separated, cleaned, weighed and converted into grain yield $\left(\mathrm{kg} \mathrm{ha}^{-1}\right)$. The harvest index for each treatment was calculated by using the following formula:

$$
\text { Harvest index }=\frac{\text { Grain yield }}{\text { Biomass yield }} \times 100
$$

\section{Statistical analysis}

Data was statistically analyzed according to Steel et al. (1996) and means was composed using LSD test $(\mathrm{P}<0.05)$.

\section{RESULTS}

\section{Plant growth}

Number of leaves plant ${ }^{-1}$ and mean leaf area was significantly affected by control vs. rest, cattle dung, $\mathrm{K}$ levels and $\mathrm{K}$ application timing, while all interactions were found non-significant (Table 1). The treated plots (rest) had significantly maximum number of eaves plant ${ }^{-1}$ and mean single leaf area than control (Table 2). Maximum number of leaves plant ${ }^{-1}$ and mean single leaf area was recorded from the field applied cattle dung as compared to the field without cattle dung. Among the three K levels, the maximum number of leaves plant ${ }^{-1}$ and mean single leaf area was recorded for the plots treated with the highest K level $\left(90>60>30 \mathrm{~kg} \mathrm{ha}^{-1}\right)$. Among the three $\mathrm{K}$ application timings, maximum number of leaves plant and mean single leaf area was recorded for the plots which 
Table 1: Analysis of variance for number of leaves plant ${ }^{-1}$, mean leaf area $\left(\mathrm{cm}^{2}\right)$, dry matter partitioning into stem, leaf, ear and total ( $\left.\mathrm{g} \mathrm{plant}^{-1}\right)$ at silking of maize (Zea mays $\mathrm{L}$.) as affected by potassium (K) levels $\left(\mathrm{kg} \mathrm{ha}^{-1}\right)$ and its application time with and without cattle dung (CD)

\begin{tabular}{lccccccc}
\hline Source of variance & $\begin{array}{c}\text { Degree of } \\
\text { freedom }\end{array}$ & $\begin{array}{c}\text { Leaves } \\
\text { plant }\end{array}$ & $\begin{array}{c}\text { Mea leaf } \\
\text { area } \mathbf{( \mathbf { c m } ^ { 2 } )}\end{array}$ & $\begin{array}{c}\text { Stem dry matter } \\
(\mathbf{g ~ p l a n t}\end{array}$
\end{tabular}

作 ( ) stands for splits of 9 degrees of freedom

Table 2: Number of leaves plant ${ }^{-1}$, mean leaf area $\left(\mathrm{cm}^{2}\right)$, dry matter partitioning into stem, leaf, ear and total $\left(\mathrm{g} \mathrm{plant}^{-1}\right)$ at silking of maize (Zea mays L.) as affected by potassium (K) levels $\left(\mathrm{kg} \mathrm{ha}^{-1}\right)$ and its application time with and without cattle dung (CD)

\begin{tabular}{|c|c|c|c|c|c|c|}
\hline Treatments & $\begin{array}{l}\text { Leaves } \\
\text { plant }^{-1}\end{array}$ & $\begin{array}{l}\text { Mean leaf } \\
\text { area }\left(\mathrm{cm}^{2}\right)\end{array}$ & $\begin{array}{l}\text { Stem dry matter } \\
\left(\text { g plant }^{-1}\right)\end{array}$ & $\begin{array}{l}\text { Leaf dry matter } \\
\quad\left(\text { g plant }^{-1}\right)\end{array}$ & $\begin{array}{l}\text { Ear dry matter } \\
\left(\text { g plant }^{-1}\right)\end{array}$ & $\begin{array}{l}\text { Total dry matter } \\
\left(\text { g plant }^{-1}\right)\end{array}$ \\
\hline $30 \mathrm{~kg} \mathrm{~K} \mathrm{ha}^{-1}$ & $11 b^{\dagger}$ & $351.2 \mathrm{~b}$ & $38.6 \mathrm{c}$ & $31.8 c$ & $56.6 \mathrm{c}$ & $127.0 \mathrm{c}$ \\
\hline $60 \mathrm{~kg} \mathrm{~K} \mathrm{ha}^{-1}$ & $11 b$ & $367.1 a$ & $46.5 b$ & $33.4 \mathrm{~b}$ & $60.4 \mathrm{~b}$ & $140.4 b$ \\
\hline $90 \mathrm{~kg} \mathrm{~K} \mathrm{ha}^{-1}$ & $12 a$ & $373.6 a$ & $50.3 a$ & $35.3 a$ & $64.9 a$ & $150.6 a$ \\
\hline $100 \% \mathrm{~K}$ at sowing & $12 \mathrm{a}$ & $364.1 a b$ & $46.1 \mathrm{a}$ & $33.1 b$ & $61.3 a$ & $140.5 a$ \\
\hline $100 \% \mathrm{~K}$ at $\mathrm{V} 9$ stage & $11 b$ & $354.9 b$ & $42.5 b$ & $32.6 b$ & $59.0 \mathrm{~b}$ & $134.1 \mathrm{~b}$ \\
\hline $50 \% \mathrm{~K}$ each at sowing and $\mathrm{V} 9$ stage & $12 \mathrm{a}$ & $372.9 a$ & $47.0 \mathrm{a}$ & $34.7 a$ & $61.7 a$ & $143.4 \mathrm{a}$ \\
\hline With cattle dung & $12 \mathrm{a}$ & $382.3 a$ & $48.1 \mathrm{a}$ & $34.5 a$ & $62.0 \mathrm{a}$ & $144.6 a$ \\
\hline Without cattle dung & $11 b$ & $345.7 b$ & $42.2 b$ & $32.5 b$ & $59.3 b$ & $134.1 \mathrm{~b}$ \\
\hline Control plots & $11 \mathrm{~b}$ & $337 \mathrm{~b}$ & $31.9 b$ & $28.0 \mathrm{~b}$ & $53.5 b$ & $113.5 b$ \\
\hline Treated (rest) plots & $12 a$ & $364 a$ & $45.2 a$ & $33.5 a$ & $60.6 a$ & $139.3 a$ \\
\hline
\end{tabular}

means of the same category followed by different letters are significantly different from each other using LSD test $(\mathrm{P} \leq 0.05)$

received $\mathrm{K}$ in two equal splits $(50 \%$ split at sowing and V9 stage $>100 \%$ at sowing $>100 \%$ at V9 stage).

\section{Dry matter partitioning}

Statistical analysis of data revealed that dry matter partitioning into stem, leaf, ear and total dry matter accumulation per plant at silking was significantly affected by control vs. rest, cattle dung, $\mathrm{K}$ levels and $\mathrm{K}$ application timing, while all interaction were found non-significant (Table 1). At silking, the treated plots had significantly higher stem, leaf, ear and total dry matter $\left(\mathrm{g}\right.$ plant $\left.^{-1}\right)$ than control (Table 2). The highest stem, leaf, ear and total dry matter $\left(\mathrm{g}\right.$ plant $\left.\mathrm{t}^{-1}\right)$ was recorded from the field under cattle dung $\left(5 \mathrm{t} \mathrm{ha}^{-1}\right)$ as compared to the field without cattle dung $\left(0 \mathrm{t} \mathrm{ha}^{-1}\right)$ at silking of maize. Among the $\mathrm{K}$ levels, the highest stem, leaf, ear and total dry matter $\left(\mathrm{g}\right.$ plant $\left.{ }^{-1}\right)$ was recorded for the plots treated with the highest $\mathrm{K}$ level $\left(90>60>30 \mathrm{~kg} \mathrm{ha}^{-1}\right)$ at silking. Among the three $\mathrm{K}$ application timings, maximum stem, leaf, ear and total dry matter per plant $(\mathrm{g})$ was recorded for the plots which received $\mathrm{K}$ in two equal splits $(50 \%$ split at sowing and V9 stage $>100 \%$ at sowing $>100 \%$ at V9 stage) at silking (Table 2).

The ANOVA table (Table 3) indicated that dry matter partitioning into stem, leaf, ear and total dry matter accumulation per plant at physiological maturity was significantly affected by control vs. rest, cattle dung, $\mathrm{K}$ levels and $\mathrm{K}$ application timing, while all interaction were found non-significant. The treated plots also had significantly higher stem, leaf, ear and total dry matter $\left(\right.$ g plant $\left.^{-1}\right)$ than control at physiological maturity (Table 4). The highest stem, leaf, ear and total dry matter ( $\left(\right.$ plant $\left.^{-1}\right)$ at physiological maturity was recorded from the field under 
Table 3: Analysis of variance for dry matter partitioning into stem, leaf, ear and total $\left(\mathrm{g} \mathrm{plant}^{-1}\right)$ at physiological maturity, biomass yield $\left(\mathrm{kg} \mathrm{ha}^{-1}\right)$ and harvest index (\%) of maize (Zea mays L.) as affected by potassium (K) levels (kg ha-1) and its application time with and without cattle dung (CD)

\begin{tabular}{|c|c|c|c|c|c|c|c|}
\hline Source of variance & $\begin{array}{l}\text { Degree of } \\
\text { freedom }\end{array}$ & $\begin{array}{l}\text { Stem dry matter } \\
\left(\text { g plant }^{-1}\right)\end{array}$ & $\begin{array}{l}\text { Leaf dry matter } \\
\quad\left(\mathrm{g} \mathrm{plant}^{-1}\right)\end{array}$ & $\begin{array}{l}\text { Ear dry matter } \\
\quad\left(\text { g plant }^{-1}\right)\end{array}$ & $\begin{array}{l}\text { Total dry matter } \\
\left(\text { g plant }^{-1}\right)\end{array}$ & $\begin{array}{l}\text { Biomass yield } \\
\left(\mathrm{kg} \mathrm{ha}^{-1}\right)\end{array}$ & $\begin{array}{c}\text { Harvest } \\
\text { index }(\%)\end{array}$ \\
\hline Cattle dung (CD) & 1 & $\star * \star \star \dagger$ & * & 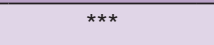 & $\star * \star$ & $\star \star \star$ & ns \\
\hline Replications (CD) & 4 & ns & ns & ns & ns & ns & ns \\
\hline Treatment $(\mathrm{Tr})$ & 9 & $* * *$ & $* \star *$ & $* * *$ & $* * *$ & $* \star *$ & ns \\
\hline Control vs rest & 1 & $* * *$ & $* \star *$ & $* * *$ & $* * *$ & $* * *$ & ns \\
\hline Application timing ( $\mathrm{T}$ ) & 2 & $\star \star \star *$ & $\star \star \star \star ~$ & $* \star \star$ & $* * *$ & * & ns \\
\hline K Levels (K) & 2 & $\star \star \star *$ & $\star \star \star \star ~$ & $\star \star \star \star ~$ & $* * *$ & $* * *$ & * \\
\hline $\mathrm{T} \times \mathrm{KL}$ & 4 & ns & ** & ns & ns & ns & ns \\
\hline $\mathrm{CD} \times \mathrm{Tr}$ & 9 & * & ns & $* *$ & $* *$ & ns & ns \\
\hline$C D \times$ control vs rest & 1 & ns & ns & 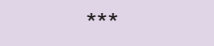 & $* *$ & ns & ns \\
\hline $\mathrm{CD} \times \mathrm{T}$ & 2 & * & ns & ns & ns & ns & ns \\
\hline $\mathrm{CD} \times \mathrm{K}$ & 2 & ns & ns & $\star \star \star ~$ & $* *$ & ns & ns \\
\hline $\mathrm{CD} \times \mathrm{T} \times \mathrm{K}$ & 4 & ns & ns & ns & ns & ns & ns \\
\hline Error & 36 & - & - & - & - & - & - \\
\hline Total & 59 & - & - & - & - & - & - \\
\hline CV-I (\%) & 3.71 & 3.97 & 3.80 & 2.21 & 3.79 & 5.01 & - \\
\hline CV-II (\%) & 3.04 & 2.59 & 3.73 & 2.33 & 3.41 & 5.72 & - \\
\hline
\end{tabular}

t,*,**,*** indicates that data is significant at 5,1 and $0.1 \%$ level of probability, respectively. The word ns stand for the non-significant data at $5 \%$ level of probability. ( ) stands for splits of 9 degrees of freedom

Table 4: Dry matter partitioning into stem, leaf, ear and total $\left(\mathrm{g} \mathrm{plant}^{-1}\right)$ at physiological maturity, biomass yield $\left(\mathrm{kg} \mathrm{ha}^{-1}\right)$ and harvest index (\%) of maize (Zea mays L.) as affected by potassium (K) levels ( $\left.\mathrm{kg} \mathrm{ha}^{-1}\right)$ and its application time with and without cattle dung (CD)

\begin{tabular}{|c|c|c|c|c|c|c|}
\hline Treatments & $\begin{array}{l}\text { Stem dry matter } \\
\left(\text { g plant }^{-1}\right)\end{array}$ & $\begin{array}{l}\text { Leaf dry matter } \\
\quad\left(\mathrm{g} \mathrm{plant}^{-1}\right)\end{array}$ & $\begin{array}{l}\text { Ear dry matter } \\
\left(\text { g plant }^{-1}\right)\end{array}$ & $\begin{array}{l}\text { Total dry matter } \\
\left(\text { g plant }^{-1}\right)\end{array}$ & $\begin{array}{l}\text { Biomass yield } \\
\left(\mathrm{kg} \mathrm{ha}^{-1}\right)\end{array}$ & $\begin{array}{l}\text { Harvest } \\
\text { index }(\%)\end{array}$ \\
\hline $30 \mathrm{~kg} \mathrm{~K} \mathrm{ha}^{-1}$ & $71.9 \mathrm{c}^{\dagger}$ & $20.0 \mathrm{c}$ & $122.6 \mathrm{c}$ & $214.4 \mathrm{c}$ & $10687 c$ & $36.9 \mathrm{~b}$ \\
\hline $60 \mathrm{~kg} \mathrm{~K} \mathrm{ha}^{-1}$ & $74.6 b$ & $23.8 b$ & $131.2 b$ & $229.6 b$ & $11457 b$ & $38.1 \mathrm{ab}$ \\
\hline $90 \mathrm{~kg} \mathrm{~K} \mathrm{ha}^{-1}$ & $85.0 \mathrm{a}$ & $27.2 \mathrm{a}$ & $137.9 a$ & $250.1 \mathrm{a}$ & $11766 a$ & $39.2 \mathrm{a}$ \\
\hline $100 \% \mathrm{~K}$ at sowing & $77.9 b$ & $23.6 b$ & $130.0 b$ & $231.6 a$ & $11265 a b$ & $38.5 a$ \\
\hline $100 \% \mathrm{~K}$ at $\mathrm{V} 9$ stage & $73.3 c$ & $22.4 c$ & $126.9 b$ & $222.5 \mathrm{c}$ & $11142 b$ & $37.4 a$ \\
\hline $50 \% \mathrm{~K}$ each at sowing and $\mathrm{V} 9$ stage & $80.3 a$ & $25.0 \mathrm{a}$ & $134.8 \mathrm{a}$ & $240.0 a$ & $11503 a$ & $38.3 a$ \\
\hline With cattle dung & $81.0 \mathrm{a}$ & $24.1 \mathrm{a}$ & $140.2 a$ & $245.4 a$ & $11728 a$ & 38.4 \\
\hline Without cattle dung & $73.4 b$ & $23.2 b$ & $120.9 b$ & $217.4 b$ & $10879 b$ & 37.7 \\
\hline Control plots & $40.3 b$ & $18.5 b$ & $110.3 b$ & $169.1 \mathrm{~b}$ & $9936 b$ & $37.4 b$ \\
\hline Treated (rest) plots & $77.2 \mathrm{a}$ & $23.7 a$ & $130.6 a$ & $231.4 a$ & $11304 a$ & $38.1 \mathrm{a}$ \\
\hline
\end{tabular}

means of the same category followed by different letters are significantly different from each other using LSD test (P $\leq 0.05)$

cattle dung $\left(5 \mathrm{tha}^{-1}\right)$ as compared to the field without cattle dung $\left(0 \mathrm{t} \mathrm{ha}^{-1}\right)$. Among the $\mathrm{K}$ levels, the highest stem, leaf, ear and total dry matter ( $g$ plant $\left.{ }^{-1}\right)$ was recorded for the plots treated with the highest $\mathrm{K}$ level $\left(90>60>30 \mathrm{~kg} \mathrm{ha}^{-1}\right)$ as shown in Table 4 . Among the three $\mathrm{K}$ application timings (Table 4), maximum stem, leaf, ear and total dry matter per plant $(\mathrm{g})$ was recorded for the plots which received $\mathrm{K}$ in two equal splits $(50 \%$ split at sowing and V9 stage $>100 \%$ at sowing $>100 \%$ at V9 stage).

\section{Biomass yield and harvest index}

Biomass yield of maize was significantly affected by control vs. rest, cattle dung, $\mathrm{K}$ levels and $\mathrm{K}$ application timing, while all interaction were found non-significant (Table 3). The treated plots (rest) had significantly higher biomass yield (11304 kg ha-1) than control (9936 kg ha-1) (Table 4).
The highest biomass yield (11728 kg ha $\left.\mathrm{kg}^{-1}\right)$ was obtained from the field applied with cattle dung as compared to field without cattle dung (10879 $\left.\mathrm{kg} \mathrm{ha}^{-1}\right)$. Among the K levels, the highest biomass yield (11766 $\mathrm{kg} \mathrm{ha}^{-1}$ ) was recorded for the plots treated with the highest $\mathrm{K}$ level $\left(90 \mathrm{~kg} \mathrm{ha}^{-1}\right)$, followed by $\left(11457 \mathrm{~kg} \mathrm{ha}^{-1}\right)$ with $60 \mathrm{~kg} \mathrm{~K} \mathrm{ha}^{-1}$, while the lowest biomass yield $\left(10687 \mathrm{~kg} \mathrm{ha}^{-1}\right)$ was obtained from the plots that received $30 \mathrm{~kg} \mathrm{~K} \mathrm{ha}^{-1}\left(90>60>30 \mathrm{~kg} \mathrm{~K} \mathrm{ha}^{-1}\right)$. the $\mathrm{K}$ application timing, the highest biomass yield (11503 $\left.\mathrm{kg} \mathrm{ha}^{-1}\right)$ was recorded for the plots which received $\mathrm{K}$ in two equal splits (50\% $\mathrm{K}_{2} \mathrm{O}$ at sowing time $+50 \% \mathrm{~K}_{2} \mathrm{O}$ at V9 stage), followed by in the plots which received $100 \% \mathrm{~K}_{2} \mathrm{O}$ at sowing time $\left(11265 \mathrm{~kg} \mathrm{ha}^{-1}\right)$ which was at par with $100 \% \mathrm{~K}_{2} \mathrm{O}$ applied at V9 stage (Table 4). The analysis of data revealed that harvest index (\%) of maize was significantly affected by control vs. rest, $\mathrm{K}$ levels, while cattle dung, $\mathrm{K}$ application 
timing and all interaction were found non-significant (Table 3). The treated plots (rest) had higher harvest index (38.1\%) than control with $37.4 \%$ (Table 4). Among the K levels, the highest harvest index $(39.2 \%)$ was recorded for the plots treated with the highest $\mathrm{K}$ level $\left(90 \mathrm{~kg} \mathrm{ha}^{-1}\right)$, followed by $38.1 \%$ with $60 \mathrm{~kg} \mathrm{~K} \mathrm{ha-1}$, while the lowest harvest index $(36.9 \%)$ was obtained from the plots that received $30 \mathrm{~kg} \mathrm{~K}$ $\mathrm{ha}^{-1}$. Though the effect of cattle dung was non-significant, however, harvest index was higher $(38.4 \%)$ for the field under cattle dung than without cattle dung (37.7\%).

\section{DISCUSSION}

Application of potassium (K) at the highest rate $\left(90 \mathrm{~kg} \mathrm{ha}^{-1}\right)$ improved growth variables such as number of leaves plant ${ }^{-1}$ and mean leaf area of maize. According to Akhtar et al. (2003) and Asif et al. (2007), the main reason for improved mean leaf area at higher $\mathrm{K}$ level could be attributed to the activation of several enzymes, increase in protein synthesis, $\mathrm{N}$ uptake and utilization that resulted in the normal growth of maize and hence leaf number and area was increased. Number of leaves plant ${ }^{-1}$ and mean leaf area of maize was significantly increased when $\mathrm{K}$ was applied in two equal splits (50\% each at sowing and V9 stage). Due to split application of $\mathrm{K}$, the maize plants probably may have absorbed more $\mathrm{K}$ with the passage of time during their growth period (Saleem et al., 2011) and hence both leaf number and area was increased. The single application of $\mathrm{K}$ at early (sowing) or late (V9 stage) growth stages on the other hand caused the plants to be under $\mathrm{K}$ stress and did not provided sufficient amount of $\mathrm{K}$ to be available for the plants at different growth stages probably may have decreased photosynthesis (Hermans et al., 2006) and enzymes activation (Evans and Wildes, 1971) therefore reduced both leaf number and area. In contrast to our results, other scientists (Chaudary and Malik, 2000) found no significant differences in maize growth parameters under different $\mathrm{K}$ levels. The experiment under cattle dung performed better in terms of higher number of leaves plant $^{-1}$ and mean leaf area in maize. According to Rahman et al. (2008), application of cattle slurry did not showed a significant effect on number of leaves but the average leaf area plant ${ }^{-1}$ was increased significantly. The increase in number of leaves plant ${ }^{-1}$ and leaf area plant ${ }^{-1}$ with organic fertilizer application was reported earlier Goenadi (1985). Mhlontlo et al. (2007) found significant increase in number of leaves with an increase in sheep manure application rate. Cow dung manure greatly improve water holding capacity, soil aeration, soil structure, nutrient retention and microbial activity in the soil (Anon, 2007; Fageria, 2009) and the increase availability of nutrients from cow manure in the soil improve growth and development in crops (Anon, 2007). Mahadi et al. (2012) reported that leaf area index increases with application of cow dung.
Increasing $\mathrm{K}$ level up to $90 \mathrm{~kg} \mathrm{ha}^{-1}$, application of $\mathrm{K}$ in two equal splits, and application of dung increased partitioning of dry matter into various plant parts of maize. The probable reason for improvement in dry matter partitioning at higher levels of $K$, split application of $K$ and cattle dung was due to the prolonged vegetative growth and higher crop growth rates (data not shown). The increase in number of leaves and area of maize showed positive relationship with increase in dry matter partioning and total dry matter accumulation. According to Baque et al. (2006), dry matter partitioning increases with K application. Amanullah et al. (2007) reported that stover yield in maize increased with application of $\mathrm{K}$ splits. Detpiratmongkol et al. (2014) compared different organic manures and reported that the maximum stem dry weight of $11.06 \mathrm{~g}$ plant $^{-1}$ was obtained in plots under chicken manure whereas the cow dung gave the lowest stem dry weight $(6.37 \mathrm{~g}$ plant $\left.^{-1}\right)$. The trend of increasing leaf dry weight with the application of organic manure was earlier reported by Goenadi (1985). Application of organic manure probably may have increased the availability of nutrients and water holding capacity of the soil resulted in enhanced growth and yield (Manhas and Gill, 2010; Abdelrazzag, 2002; Rashid et al., 2013; Hidyatullah et al., 2013). According to several researchers (Mhlontlo et al., 2007; Sanjutra et al., 2008; Ramesh et al., 2011; Mishra and Jain, 2013) reported increase in dry matter with application of sheep manure.

Biomass yield increased with $\mathrm{K}$ application at the highest rate of $90 \mathrm{~kg} \mathrm{ha}^{-1}, \mathrm{~K}$ applied in two equal splits, and application of cattle dung. The probable reason for increase in biomass yield of maize with $\mathrm{K}$ application probably might be due to the increased rate of $\mathrm{CO}_{2}$ assimilation, stabilized the stomata regulation, improved stomata closure and enzyme activity as a result of which more carbohydrates might have produced and hence increased biomass yield (Tabatabaii et al., 2011). Choudhry and Malik (2000), and Sharif and Hussain (1993) also noted a significant increase in biomass yield of maize with $\mathrm{K}$ application over the control plots. The increase in biomass yield with $\mathrm{K}$ split application reflects the better growth and development of the plants due to more availability of nutrients throughout the growing period of maize (Asif et al., 2007; Amanullah et al., 2007). The increase in biomass yield of maize with application of cattle dung probably may be due to the improved soil physico-chemical properties, enhanced soil nutrients and organic matter content, improved soil $\mathrm{pH}$ and CEC and the improved activity of soil organisms (Fageria, 2009; Hidayatullah et al., 2013). Haghighat et al. (2013) found that sweet corn biomass yield increased with application of cattle manure. Several other researchers revealed that organic manuring increased the vegetative growth and biomass production Ibeawuchi et al., 2007; Roy and Hore, 2010; Dinesh et al., 2010; Mahadi et al. (2012). 
Harvest index was higher when $\mathrm{K}$ was applied at rate of $90 \mathrm{~kg} \mathrm{ha}^{-1}$. The increase in harvest index with higher $\mathrm{K}$ level was attributed to the more dry matter partitioning into the reproductive parts (ears) of maize. The increase in $\mathrm{K}$ level increased yield and yield components of maize $\left(1^{\text {st }}\right.$ paper submitted from this study) and hence the harvest index was also increased with increase in $\mathrm{K}$ level. Because the increase in grain yield and yield components had positive relationship with harvest index in maize crop (Amanullah, 2014). In our experiment both field under with and without cattle dung had statistically the same harvest index. However, the field under cattle dung produced relatively higher harvest index than the field where no cattle dung was applied. Improvement in harvest index was reported earlier by Fallah et al. (2007) and Mahadi et al. (2012) in maize, and Haghighat et al. (2013) in sweet corn. Ogbonna and Obi (2005) reported that increase in organic manure application resulted in high dry matter partitioning and therefore increased grain yield and higher harvest index.

\section{CONCLUSIONS}

The potassium $(\mathrm{K})$ treated plots had better performance in terms of improved leaf number and mean leaf area, dry matter partitioning, biomass yield and harvest index than control (no K applied). Application of $\mathrm{K}$ at the highest rate of $90 \mathrm{~kg} \mathrm{~K} \mathrm{ha}{ }^{-1}$ improved leaf number and mean leaf area, dry matter partitioning, biological yield and harvest index of maize. Application of $\mathrm{K}$ in two equal splits (50\% at sowing and 50\% at V9 stage) improved leaf number and mean leaf area, dry matter partitioning, biomass yield and harvest index. The experiment under cattle manure $\left(5 \mathrm{t} \mathrm{ha}^{-1}\right)$ had better growth (more leaf number and mean leaf area), higher dry matter partitioning into different plant parts, and higher biomass yield than the experiment where cattle manure was not applied. Application of $\mathrm{K}$ at the highest rate of $90 \mathrm{~kg} \mathrm{ha}+$ in two equal splits (50\% at sowing and $50 \%$ at V9 stage) along with cattle manure $\left(5 \mathrm{tha}^{-1}\right)$ could increase crop growth and productivity under calcareous soils.

\section{Author contributions}

A.: Designed the study, supervised the research project. A. I.: Conducted the field experiment, took the data, did the analysis, wrote the report and this manuscript. M. I.: Downloaded related literature for this manuscript and and also corrected the article.

\section{REFERENCES}

Abdelrazzag, A. 2002. Effect of chicken manure, sheep manure and inorganic fertilizer on yield and nutrients uptake by onion. Pak. J. Bio. Sci. 5(3): 266-268.
Adepetu, I. O., O. E. Akirinade and J. O. Azeaz. 2005. Influence of combined application of cattle manure and NPK fertilizer on soil chemical properties, growth and yield of Okra (Abelmoschus esculentum) in Alfisol Proceedings of the $29^{\text {th }}$ Annual Conference of the Soil Science Society of Nigeria, December 6-10, 2004, University of Agriculture, Abeokuta, Nigeria. p. 143-146.

Ahmad, N and M. Rashid. 2003. Fertilizers and their use in Pakistan. Extension Bulletin. NDFC. Islamabad. p. 112.

Akhtar, M. E., M. T. Saleem and M. D. Stauffer. 2003. Potassium in Pakistan Agriculture. Pakistan Agriculture Research Council, Islamabad.

Amanullah. 2014. Source and rate of nitrogen application influence agronomic $\mathrm{N}$-use efficiency and harvest index in maize (Zea mays L) genotypes. Maydica, 59: 80-89.

Amanullah, S. Shah, Z. Shah and S. K. Khalil. 2014. Effects of variable nitrogen source and rate on leaf area index and total dry matter accumulation in maize (Zea mays L.) genotypes under calcareous soils. Turk. J. Field Crops, 19(2): 276-284.

Amanullah, M. Asif and L. K. Almas. 2012. Agronomic efficiency and profitability of $\mathrm{P}$-fertilizers applied at different planting densities of maize in Northwest Pakistan. J. Plant Nutr. 35: 331-341.

Amanullah, M. Hassan and S. S. Malhi. 2011. Seed yield and yield components response of rape ( $B$. napus) versus mustard (B. juncea) to sulfur and potassium fertilizer application in Northwest Pakistan. J. Plant Nutr. 34: 1164-1174.

Amanullah and M. W. Khan. 2010. Interactive effects of potassium and phosphorus application on phenology and grain yield of sunflower in Northwest Pakistan. Pedosphere, 20: 674-680.

Amanullah, L. K. Almas and P. Shah. 2010a. Timing and rate of nitrogen application influence profitability of maize planted at low and high densities in Northwest Pakistan. Agronomy J. 102: 575-579.

Amanullah, J., M. Yasir, S. K. Khalil, M. T. Jan and A. Z. Khan. 2010b. Phenology, growth, and grain yield of maize as influenced by foliar applied urea at different growth stages. J. Plant Nutr. 33: 71-79.

Amanullah, R. A. Khattak and S. K. Khalil. 2009. Effects of plant density and $\mathrm{N}$ on phenology and yield of maize. J. Plant Nutr. 32(2): 246-260.

Amanullah, M. Asif, Z. Shah and M. Hassan. 2007. Potassium effects on the yield and yield components of maize in Northwest Pakistan. Ann. Agrarian Sci. 5(4): 13-17.

Anon. 2007. Effects of organic and inorganic nutrient sources on soil mineral nitrogen and maize yield in western Kenya. Available from: http://www.agnet. org.

Asif, M., Amanullah, and M. Anwar. 2007. Phenology, leaf area and yield of spring maize (Cv. Azam) as affected by levels and timings of potassium application. World Applied Sci. J. 2(4): 299-303.

Ayoola, O. T and E. A. Makinde. 2008. Performance of green maize and soil nutrient changes with fortified cow dung. Afr. J. Plant Sci. 2(3): 19-22.

Bahman, E. and F. P. James. 1999. Composted and non-composted manure application to conventional and no tillage systems in corn yield and nitrogen uptake. Agron. J. 91: 819.

Baque, M. A., M. A. Karim, A. Hamid and H. Tetsushi. 2006. Effect of fertilizer potassium on growth, yield and nutrient uptake (Triticum aestivum) under water stress conditions. J. South Pac. Stud. 27(1): 25-35.

Chaudhry, A. and J. K. Malik. 2000. Determination of optimum level of potash and its effect on yield and quality of maize. Pak. J. Bio. Sci. 3(12): 75-80.

Das, K. C., A. Mishra, and J. Pandy. 1976. Split application of potash for rice. Indian Potash. J. 1(1): 13-16.

Detpiratmongkol, S. T. Ubolkerd, and S. Yoosukyingstaporn. 2014. 
Effects of chicken, pig and cow manures on growth and yield of Kalmegh (Andrographis paniculata Nees). J. Agric. Technol. 10(2): 475-482.

Dinesh, R., V. Srinivasan, S. Hamja and A. Mahjusha. 2010. Short term incorporation of organic manures and fertilizers influences biochemical and microbial characteristics of soil under an annual crop turmeric. Biores. Tech. 101(12): 4697-4702.

DIPA. 2006. Handbook of Agriculture: Facts and Figures for Farmers, Students and all Interested in Farming. Directorate of Information and Publications of Agriculture. Indian Council of Agricultural Research, New Delhi. p435.

Ebrahimi, S. T., M. Yarnia, M. B. K. Benam and E. F. M. Tabrizi. 2011. Effect of potassium fertilizer on corn yield (Jeta cv.) under drought stress condition. American-Eurasian. J. Agric. Environ. Sci. 10(2): 257-263.

Evans, H. and R. A. Wildes. 1971. Potassium and its role in the enzyme activation. In Potassium its biochemistry and physiology. Proceedings Colloquium of the International Potash Institute. Vol. 8. p13-29.

Fallah, S., A. Ghalavand and M. R. Khajehpour. 2007. Effects of cattle dung incorporation methods and its integration with chemical fertilizer on yield and yield components of maize (Zea mays $L$ ) in Khorramabad, Lorestan. JWSS - Isfahan Univ. Technol. 11(40): 233-243.

Fageria, N. K. 2009. The Use of Nutrients in Crop Plants. CRC Press, USA.

Goenadi, D. H. 1985. Effect of FYM, NPK and liquid fertilizer on Stevia rebaudiana. Menera Perkebunan. 53: 23-30.

Haghighat, A., A. Hossein, S. Rad and S. Seyfzadeh. 2013. Effect cattle manure and plant density on Morpho-physiological traits of sweet corn in second cultivation by different culture methods. Int. J. Agric. Crop Sci. (2): 177-182.

Hermans, C., P. J. Hammond, P. J. White and N. Verbruggen. 2006. How do plants respond to nutrient shortage by biomass allocation? Trends Plant Sci. 11: 610-617.

Hidayatullah, A., Amanullah, Jr., A. Jan and Z. Shah. 2013. Residual effect of organic nitrogen sources applied to rice on the subsequent wheat crop. Int. J. Agron. Plant Prod. 4: 620-631.

Ibeawuchi, I. I., F. A. Opara, C. T. Tom and J. C. Obiefuna. 2007. Graded replacement of inorganic with organic manure for sustainable maize production in Owerri Imo Sta Nigeria. Life Sci. J. 4(2): 82-87.

Ismail, A. S., A. S. El-Schaay, S. A. Salehu and A. F. Abdel-Wahab. 1999. Effect of application of mineral and organic amendment of nodulation of cowpea growth and certain chemical properties of calcareous soil. Ann. Agric. Sci. (Special Edition): 23-39.

Mahadi, M. A., S. A. Dadari, B. Tanimu, N. C. Kuchinda, A. I. Sharifai, and M. S. Bature. 2012. Effects of weed control and cow dung manure on growth indices of quality protein maize. Bayero $\mathrm{J}$. Pure Appl. Sci. 5(2): 148-155.

Malik, D. M., R. A. Chaudhary and G. Hussain. 1989. Crop responses to potash application in the Punjab. Proceeding of workshop on the role of potassium in improving fertilizer use efficiency. National Fertilizer Development Centre, Islamabad. p. 71-93.

Manhas, S. S and S. B. Gill. 2010. Effect of planting materials, mulch levels and farmyard manure on growth, yield and quality of turmeric (Curcuma longa L). Indian J. Agric. Sci. 80(6): 227-233.

Materechera, S. A. 2010. Utilization and management practices of cattle dung for replenishing soil fertility among small scale crop farmers in semi-arid farming districts of the North West Province, South Africa. Nutr. Cycl. Agroecosyst. 87: 415-428.

Mengel, K., E. A. Kirkby, H. Kosegarten and T. Appel. 2001. Principles of Plant Nutrition. $5^{\text {th }}$ ed. Kluwer Academic Publishers, Dordrecht, Netherlands.
Mhlontlo, S., P. Muchaonyerwa and P. N. S. Mnkeni. 2007. Effects of sheep kraal manure on growth, dry matter yield and leaf nutrient composition of a local amaranthus accession in the central region of the Eastern Cape Province, South Africa. 33(3): 363368. Available from: http://www.wrc.org.za.

MINFAL. 2012. Agricultural statistics of Pakistan. Goverment of Pakistan. Ministry of Food Agriculture. Livestock, Food Agricultural and Livestock, Division (Economic wing) Islamabad.

Mishra, S. and A. Jain. 2013. Effect of integrated nutrient management on and rographolide content of Andrographis paniculata. Nat. Sci. 11(8): 30-32.

Ogbonna, P. E. and I. U. Obi. 2005. Effect of time of planting and poultry manure application on growth and yield of maize (Zea mays L) in a derived savannah Agro-ecology. Agro-Sci. J. Trop. Agric., Food, Env. Ext. 2: 133-38.

Olayinka, A. 1996. Carbon mineralization from poultry manure, straw and sawdust amended alfisol. J. Agric. 2(18): 26-36.

Olayinka, A., A. Adentunyi and A. Adebayo. 1998. Effect of organic amendment on nodulation and nitrogen fixation of cowpea. J. Plant Nutr. 21(11): 2455-464.

Rahman, S. M. E., M. A. Islam, M. M. Rahman, and O. Deog-Hwan. 2008. Effect of cattle slurry on growth, biomass yield and chemical composition of maize fodder. Asian-Aust. J. Anim. Sci. 21(11): 1592-1598.

Ramesh, G., M. B. Shivanna and A. Santa Ram. 2011. Interactive influence of organic manure and inorganic fertilizers on growth and yield of $A$. paniculata. Int. Res. J. Plant Sci. 2: 016-021.

Rashid, Z., M. Rashid, S. Inamullah, S. Rasool and F. Bahar. 2013. Effect of different levels of farmyard manure and nitrogen on the yield and nitrogen uptake by stevia (Stevia rebaudian Bertoni). Afri. J. Agric. Res. 8(29): 3941-3945.

Reijnties, C., B. Hoverkork, and A. Water-Bayer. 1992. An Introduction to Low External input and Sustainable Agriculture. John Wiley and Sons, London. p340.

Roy, S. S. and J. K. Hore. 2010. Vermiculture can be practiced in all plantation crops. A Report of Department of Spices and Plantation Crops. Faculty of Horticulture, Bidhan Chandra Krishi Viswavidyalaya, Mohanpur - 741252 Nadia, West Bengal. p20-30.

Saleem, A., H. I. Javed, R. Saleem, M. Ansar and M. A. Zia. 2011. Effect of split application of potash fertilizer on maize and sorghum in Pakistan. Pak. J. Agric. Res. 24: 1-4.

Sanjutha, S., S. Subramanian, C. Indu Rai and J. Maheswari. 2008. Integrated nutrient management of A. paniculata. Res. J. Agric. Bio. Sci. 4(2): 141-145.

Sharif, M. and S. Hussain. 1993. Maize response of potassium fertilizer at Mardan. Sarhad. J. Agric. 9(3): 257-261.

Sharma, A. R., B. N. Mittra, A. N. Sharpley and S. J. Smith. 1991. Effect of different rates of application of Nitrogen and phosphorus forms in soil receiving manure. Soil Sci. 159: 253-258.

Sharpley, A. M and. S. J. Smith. 1995. Nitrogen and phosphorus in soils receiving manure. Soil Sci. 159: 253-258.

Singh, B. B and J. P. Jones. 1975. Use of sorption-isotherms for evaluating potassium requirement of plants. Soil Sci. Soc. Am. J. 39: 881-886.

Sobulo, R. A and O. Babalola. 1992. Improved organic fertilizer and soil condition. In toward efficiency fertilizer use in Nigeria. Federal Ministry of Agriculture, Water Resources and Rural Development. Lagos. p90-110.

White, J. 2003. Potassium nutrition in Australian high-yielding maize production systems - A review. Paper Presented at the $5^{\text {th }}$ Australian Maize Conference, $18-20^{\text {th }}$ February 2003, Toowoomba, Queensland. 